\title{
PERBANDINGAN KEMAMPUAN MENGONVERSI TEKS LAPORAN HASIL OBSERVASI KE DALAM PUISI MENGGUNAKAN MODEL DISCOVERY LEARNING DAN MODEL PEMBELAJARAN LANGSUNG
}

\author{
Rini Kartini Saputri ${ }^{1}$, Abdoel Gafar ${ }^{2}$, dan Firman Tara ${ }^{3}$ \\ Program Studi Pendidikan Bahasa dan Sastra Indonesia, \\ Fakultas Keguruan dan Ilmu Pendidikan, Universitas Batanghari, \\ Jambi \\ Rinikartini456@gmail.com \\ Gafar35@yahoo.co.id \\ firmantara14@gmail.com
}

\begin{abstract}
This research is intended to identify the students ability in converting report text to a poetry that was taught by using discovery learning. This research is quantitative with quasi experimental design. The population of this research is students of class X MIPA SMA Negeri 10 Kota Jambi. In collecting sample, random sampling is used, in which class $\mathrm{X}$ MIPA1 is experiment class and class X MIPA 2 is a control class. The technique of collecting the data is test. The data is analyzed by using pretest analysis, normality test, homogeneity test, and hypothesis test. The result of the research shows that the mean score of experiment class is 75,00 and the mean score of control class is 71,80. The hypothesis test is calculated by using SPSS 20. T-test of two samples is gained with t-count $0,049<0,05$ in which $\mathrm{H}_{\mathrm{o}}$ is rejected and $\mathrm{H}_{\mathrm{a}}$ is accepted. Based on the result of the analysis, it can be concluded that students ability in converting report text into poetry can be taught by using discovery learning compared with those students who tried to convert the report text into poetry with direct learning model.
\end{abstract}

Key Words: report text, poetry, discovery learning

\footnotetext{
${ }^{1}$ Mahasiswa Program Studi pendidikan Bahasa dan Sastra Indonesia, Fakultas Keguruan dan Ilmu Pendidikan, Universitas Batanghari, Jambi

${ }^{2}$ Dosen Program Studi pendidikan Bahasa dan Sastra Indonesia, Fakultas Keguruan dan Ilmu Pendidikan,Universitas Batanghari,Jambi

${ }^{3}$ Dosen Program Studi pendidikan Bahasa dan Sastra Indonesia, Fakultas Keguruan dan Ilmu Pendidikan, Universitas Batanghari, Jambi
}

Perbandingan Kemampuan Mengonversi Teks Laporan Hasil Observasi ke dalam Puisi Menggunakan Model Discovery Learning dan Model Pembelajaran Langsung 


\section{PENDAHULUAN}

Kegiatan pembelajaran bahasa

Indonesia tidak terlepas dari keterampilan berbahasa. Keterampilan berbahasa hakikatnya mempunyai empat komponen yaitu keterampilan menyimak, berbicara, membaca dan menulis, seperti yang dikemukakan oleh Nida dan Harris (dalam Tarigan 2008:1) yaitu “(1) Keterampilan menyimak (listening skills), (2) keterampilan berbicara (speaking skills), (3) keterampilan membaca (reading skills), dan (4) keterampilan menulis (writing skills)". Menulis adalah kegiatan menyampaikan pesan (gagasan, perasaan atau informasi) secara tertulis kepada pihak lain. Menulis sebagai satu di antara keterampilan yang tidak dapat dipisahkan dari aspek-aspek keterampilan lainnya. Dengan demikian, menulis adalah hasil mengorganisasikan ide atau gagasan dari proses mendengarkan, berbicara, dan membaca.

Keterampilan menulis merupakan kemampuan berbahasa yang kompleks. Kompleksitas menulis terletak pada tuntutan kemampuan penulis untuk menata dan mengorganisasikan ide secara runtut dan logis, serta menyajikan dalam ragam bahasa tulis dan kaidah penulisan yang benar. Oleh karena itu, proses menulis memiliki beberapa tahapan yang memberi nama keseluruhan tulisan. Menurut Dalman (2014:15-20), “Tahapan menulis terdiri atas tahap prapenulisan, tahap penulisan, dan tahap pasca penulisan".

Kemampuan menulis sangat penting bagi siswa terutama bagi siswa SMA. Dengan menulis, siswa dapat menyampaikan ide atau gagasan secara tidak langsung dalam sebuah tulisan. Hal ini menunjukkan bahwa menulis adalah sebuah proses perkembangan yang membutuhkan adanya pengalaman dan latihan. Latihan diperlukan untuk mendapatkan hasil tulisan yang baik. Pengalaman latihan menulis tersebut didapatkan dari pembelajaran keterampilan menulis di sekolah. Pembelajaran menulis selalu ada di setiap kompetensi dasar, salah satunya menulis puisi sesuai standar kompetensi.

Dalam menulis puisi, siswa dituntut untuk mengungkapkan pikiran dan perasaan secara imajinatif. Dengan tujuan merangsang kepekaan terhadap keindahan dan rasa kemanusiaan, hal ini sejalan dengan tujuan menulis yang dikemukan oleh Dalman (2014:13-14), "Para sastrawan pada umumnya menulis dengan tujuan untuk menciptakan sebuah

Perbandingan Kemampuan Mengonversi Teks Laporan Hasil Observasi ke dalam Puisi Menggunakan Model Discovery Learning dan Model Pembelajaran Langsung 
keindahan (estetis) dalam sebuah puisi, cerpen, maupun novel. Untuk itu, penulis pada umumnya memperhatikan pilihan kata dan diksi serta penggunakan gaya bahasa yang tepat. Kemampuan penulis mempermainkan kata sangat dibutuhkan dalam tulisan yang memiliki tujuan estetis". Manfaat menulis puisi di antaranya mengembangkan imajinasi siswa, pengetahuan siswa akan bertambah, siswa akan lebih kreatif dalam menuangkan ide-idenya dan siswa yang paling penting siswa akan semakin terampil dalam menuangkan buah pikirannya dalam bentuk tulisan.

$$
\text { Pembelajaran keterampilan }
$$

menulis pada kurikulum 2013, memperhatikan pentingnya penggunaan bahasa sebagai wahana untuk mengekspresikan perasaan dan pemikiran secara estetis dan logis. Selain itu, kurikulum 2013 menekankan standar kompetensi pada kompetensi sikap, pengetahuan, dan keterampilan. Kurikulum yang digunakan SMA Negeri 10 Kota Jambi, pada mata pelajaran bahasa Indonesia kelas X MIPA semester ganjil mempunyai kompetensi dasar 4.5 yang diusung dalam kurikulum 2013 tentang mengonversi teks laporan hasil observasi ke dalam bentuk yang lain secara lisan maupun tulisan dengan mengambil spesifikasi menulis puisi.

Dalam kurikulum 2013, dinyatakan bahwa mengonversi teks laporan hasil observasi ke dalam bentuk yang lain, yakni mengubah teks laporan hasil observasi ke dalam bentuk pantun, puisi, cerpen atau naskah drama. Salah satunya adalah mengonversi teks laporan observasi ke dalam puisi. Teks laporan hasil observasi merupakan sebuah teks yang berisi penjabaran umum atau melaporkan sesuatu berupa hasil dari pengamatan, sedangkan puisi adalah ragam sastra yang bahasanya terikat oleh irama, matra, rima, serta penyusunan larik dan bait.

$$
\text { Sesuai dengan prinsip }
$$
pembelajaran bahasa Indonesia dalam kurikulum tersebut yakni berbasis teks. Jenis teks terbagi menjadi genre sastra dan genre faktual. Dalam hal ini sejalan dengan ragam tulis yang ditinjau dari segi bentuknya, menurut Tarigan (2008:54), "Ragam tulis di bagi atas: (1) pemberian faktual (factual deskription), (2) pemberian pribadi (personal deskription)". Hal ini berarti mengubah teks laporan hasil observasi yang merupakan teks genre faktual menjadi puisi yang tergolong teks genre sastra. 
Berdasarkan pengamatan penulis di atas, perlu adanya model pembelajaran yang mengefektifkan siswa belajar. Model discovery learning merupakan model dari metode konstruktivisme yang merupakan metode pengajaran sastra yang bersifat active learning. Ismawati (2013:50) berpendapat, "Banyak metode yang dapat dipilih dalam pengajaran sastra, namun setiap pemilihan metode harus didasarkan pada cara siswa aktif (active leaning)".

Berdasarkan pendapat pakar tersebut, model discovery learning dapat digunakan dalam pengajaran sastra keterampilan menulis puisi. Untuk itu dalam penelitian ini, peneliti memilih model pembelajaran discovery learning suatu model pembelajaran penemuan, di mana pembelajaran belum diketahui oleh siswa tidak melalui pemberitahuan guru tetapi ditemukan oleh siswa sendiri. Hal yang peneliti teliti dalam penelitian ini adalah perbandingan kemampuan mengonversi teks laporan hasil observasi ke dalam puisi siswa yang diajarkan menggunakan model pembelajaran discovery learning dan model pembelajaran langsung. Serta alasan penulis memilih model pembelajaran tersebut, untuk mengetahui kemampuan siswa dalam mengonversi teks laporan hasil observasi ke dalam puisi.

Tujuan penelitian ini adalah untuk mengetahui perbandingan kemampuan mengonversi teks laporan hasil observasi ke dalam puisi siswa yang diajarkan menggunakan model discovery learning dan model pembelajaran langsung. Penelitian ini diharapkan dapat memberikan manfaat teoretis mengenai model pembelajaran bahasa Indonesia yang tepat dan menambah pengetahuan dalam pembelajaran, terutama kemampuan mengonversi teks laporan hasil observasi ke dalam puisi menggunakan model discovery learning.

\section{METODE PENELITIAN}

Penelitian ini dilakukan dengan menggunakan metode eksperimen, karena adanya hubungan sebab akibat antara dua variabel. Arikunto (2010:9) mengatakan "Metode eksperimen adalah suatu cara untuk mencari hubungan sebab akibat (hubungan kausal) antara dua faktor yang sengaja ditimbulkan oleh penulis dengan mengeliminasi atau mengurangi atau menyisihkan faktorfaktor lain yang mengganggu”. Pendekatan yang digunakan dalam penelitian ini adalah pendekatan 
kuantitatif. Dengan demikian, pengolahan data hasil penelitian ini akan dilakukan secara statistik dan hasilnya berupa angka.

\section{Menurut Arikunto (2010:90),} "Desain penelitian adalah rencana atau rancangan yang dibuat oleh peneliti, sebagai ancar-ancar kegiatan, yang akan dilaksanakan”. Desain yang digunakan dalam penelitian ini adalah quasi experimental.

Populasi dalam penelitian ini adalah keseluruhan siswa kelas X MIPA SMA Negeri 10 Kota Jambi Tahun Ajaran 2016/2017. Penentuan sampel dalam penelitian ini secara Random sampling. Variabel bebas (X) dalam penelitian ini adalah penggunaan model discovery learning dan model pembelajaran langsung sedangkan variabel terikatnya (Y) adalah kemampuan siswa mengonversi teks laporan hasil observasi ke dalam puisi. Teknik pengumpulan data menggunakan tes. Sedangkan teknik analisis dilakukan terlebih dahulu uji persyaratan sampel, uji normalitas, homogenitas dan uji hipotesis. Pada hipotesis penelitian permasalahan penelitian yang ada dalam rumusan masalah akan dijawab dengan melakukan serangkaian pengujian hipotesis dengan taraf signifikan $\alpha=$ 0,05 .

\section{HASIL DAN PEMBAHASAN}

Penulis melaksanakan penelitian di SMA Negeri 10 Kota Jambi pada tahun tahun ajaran 2016/2017. Penelitian dilakukan di kelas X MIPA1 sebagai kelas eksperimen dan kelas X MIPA2 sebagai kelas kontrol, dalam pembelajaran mengonversi teks laporan hasil observasi ke dalam puisi pada kurikulum 2013. Pembelajaran di kelas eksperimen diajarkan menggunakan model discovery learning sedangkan kelas kontrol diajarkan menggunakan model pembelajaran langsung. Perbedaan nilai kelas eksperimen dan kelas kontrol dapat dilihat pada tabel berikut ini.

\section{Tabel 1. Hasil Belajar Mengonversi Teks Laporan Hasil Observasi ke dalam Puisi}

\begin{tabular}{cccccc}
\hline Kelas & $\mathrm{N}$ & $\begin{array}{c}\text { Nilai } \\
\text { Tertinggi }\end{array}$ & $\begin{array}{c}\text { Nilai } \\
\text { Terendah }\end{array}$ & $S$ & $\overline{\boldsymbol{X}}$ \\
\hline $\mathrm{R}_{1}$ & 36 & 90 & 65 & 6,547 & 75,00 \\
\hline $\mathrm{R}_{2}$ & 36 & 85 & 60 & 6,985 & 71,81 \\
\hline
\end{tabular}

Perbandingan Kemampuan Mengonversi Teks Laporan Hasil Observasi ke dalam Puisi Menggunakan Model Discovery Learning dan Model Pembelajaran Langsung 
Berdasarkan tabel 1. di atas, dapat diketahui bahwa hasil belajar kelas eksperimen yang berjumlah 36 siswa lebih tinggi dengan rata-rata 75,00 dibandingkan dengan kelas kontrol yang berjumlah 36 siswa dengan rata-rata 71,81 . Pada kelas eksperimen, nilai terendah yang diperoleh siswa yaitu sebesar 65 dan nilai tertinggi yang diperoleh siswa sebesar 90, sedangkan kelas kontrol nilai terendah yang diperoleh siswa sebesar 60 dan nilai tertinggi yang diperoleh siswa sebesar 85 . Simpangan baku kelas eksperimen 6,547 lebih besar dari simpangan baku kelas kontrol 6,985. Hal ini menunjukkan bahwa rata-rata kemampuan siswa mengonversi teks laporan hasil observasi ke dalam puisi yang diajarkan menggunakan model discovery learning lebih baik dari pada rata-rata kemampuan siswa yang diajarkan menggunakan model pembelajaran langsung.

Berdasarkan uji normalitas dan homogenitas yang dilakukan terhadap populasi, dapat disimpulkan bahwa populasi berdistribusi normal dan homogen. Data populasi yang dipilih menjadi sampel benar-benar dari populasi sama. Data yang dianalisis merupakan data tes unjuk kerja, langkah-langkah yang dilakukan terlebih dahulu menguji normalitas, uji homogenitas dan selanjutnya uji hipotesis terhadap hasil belajar siswa. Berdasarkan uji normalitas diketahui bahwa taraf signifiknasi kelas eksperimen adalah 0,132 yang berarti lebih besar dari taraf nyata 0,05 hal ini menunjukkan bahwa kelas eksperimen berdistribusi normal. Selanjutnya diketahui bahwa taraf siginifiknasi kelas kontrol adalah 0,405 yang berarti lebih besar dari taraf nyata 0,05 dan berdistribusi normal.

Berdasarkan uji homogenitas, diketahui bahwa taraf signifikan adalah 0,312 yang berarti lebih besar dari taraf nyata 0,05 hal ini menunjukkan bahwa kelas eksperimen dan kelas kontrol memiliki populasi yang sama. Uji hipotesis dalam penelitian ini menggunakan uji $\mathrm{t}$ dua sampel indenpenden untuk membandingkan ratarata dari kelompok tidak berhubungan satu sama lainnya. Uji $t$ dua sampel indenpendent dapat dilihat pada tabel di bawah ini.

Perbandingan Kemampuan Mengonversi Teks Laporan Hasil Observasi ke dalam Puisi Menggunakan Model Discovery Learning dan Model Pembelajaran Langsung 
Tabel 2. Uji Hipotesis

\begin{tabular}{|c|c|c|c|c|c|}
\hline Nilai & \multicolumn{2}{|c|}{$\begin{array}{l}\text { Levene's Test } \\
\text { for Equality } \\
\text { of Variances }\end{array}$} & \multicolumn{3}{|c|}{$\begin{array}{c}t \text {-test for } \\
\text { Equality of Means }\end{array}$} \\
\hline $\begin{array}{ll}\mathrm{R}_{1} & \mathrm{R}_{2}\end{array}$ & $\begin{array}{c}F \\
0338\end{array}$ & $\begin{array}{c}\text { Sig. } \\
0563\end{array}$ & $\frac{t}{2002}$ & $\begin{array}{ll}\mathrm{df} \\
70\end{array}$ & Sig. \\
\hline
\end{tabular}

Penelitian ini dilakukan di kelas $\mathrm{X}$ MIPA1 sebagai kelas eksperimen dan $\mathrm{X}$ MIPA2 sebagai kelas kontrol. Berdasarkan analisis data yang dilakukan sebelumnya, bahwa berdasarkan uji normalitas dan homogenitas yang dilakukan terhadap kedua sampel diketahui berdistribusi normal dan homogen. Maka dalam penelitian ini, kelas eksperimen diajarkan menggunakan model pembelajaran discovery learning dan kelas kontrol menggunakan model pembelajaran langsung.

Berdasarkan analisis data hasil belajar siswa mengonversi teks laporan hasil observasi ke dalam puisi, diketahui bahwa kelas eksperimen yang diajarkan menggunakan model discovery learning memperoleh nilai rata-rata 75,00. Hasil analisis data mengonversi teks laporan hasil observasi ke dalam puisi, kelas kontrol yang diajarkan menggunakan model pembelajaran langsung diperoleh nilai rata-rata 71,81 . Hal ini menunjukkan bahwa rata-rata kemampuan siswa yang diajarkan menggunakan model discovery learning labih tinggi dari pada rata-rata kemampuan siswa yang diajarkan menggunakan model pembelajaran langsung.

Analisis uji hipotesis menggunakan uji tdua sampel indenpendent diperoleh sig t hitung $0,049<0,05$. Dimana $\mathrm{H}_{\mathrm{o}}$ ditolak dan $\mathrm{H}_{\mathrm{a}}$ diterima, berarti hipotesis kemampuan mengonversi teks laporan hasil observasi ke dalam puisi yang diajarkan menggunakan model discovery learning lebih baik dari pada kemampuan mengonversi teks laporan hasil observasi kedalam puisi yang diajarkan menggunakan model pembelajaran langsung.

\section{SIMPULAN}

Berdasarkan analisis hasil penelitian, dapat disimpulkan bahwa perbandingan kemampuan siswa mengonversi teks laporan hasil observasi ke dalam puisi kelas $\mathrm{X}$ MIPA1 sebagai kelas eksperimen yang diajarkan menggunakan model discovery learning memperoleh nilai rata-rata 75,00 dengan 
simpangan baku 6,547 dan kemampuan siswa mengonversi teks laporan hasil observasi ke dalam puisi kelas X MIPA 2 sebagai kontrol yang diajarkan menggunakan model pembelajaran langsung memperoleh nilai rata-rata 71,81 dengan simpangan baku 6,985 . Berdasarkan uji hipotesis menggunakan uji tdua sampel independent, diperoleh sig $\mathrm{t}$ hitung $0,049<0,05$ maka $\mathrm{H}_{\mathrm{o}}$ ditolak dan $\mathrm{H}_{\mathrm{a}}$ diterima. Jadi dapat disimpulkan bahwa kemampuan mengonversi teks laporan hasil observasi ke dalam puisi yang diajarkan menggunakan model discovery learning lebih baik dibandingkan kemampuan mengonversi teks laporan hasil laporan observasi ke dalam puisi yang diajarkan menggunakan model pembelajaran langsung.

\section{DAFTAR PUSTAKA}

Arikunto, Suharsimi. (2010). Prosedur Penelitian Suatu Pendekatan Praktik. Jakarta: Rineka Cipta.

Dalman, H. (2014). Keterampilan Menulis. Jakarta: PT Grapindo Persada.

Ismawati, Esti. (2013). Pengajaran Sastra. Yogyakarta: Ombak.

Tarigan, Henry Guntur. (2008). Menulis Sebagai Suatu Keterampilan Berbahasa. Bandung: Angkasa. 